2 (see Mowrey et al., 1990, for origin of peach plant introductions). A similar trend was found for the Mdh 1-3 and Mdh 1-2 alleles in peach (Mowrey et al., 1990).

This study identified a new genetic marker in peach and further substantiates that the North American germplasm base of peach is very narrow. Further, allozyme variation revealed in this and a previous study (Mowrey et al., 1990) of the PI collection suggests that this collection should be examined for other valuable qualitative and quantitative traits.

\section{Literature Cited}

Ackerman, W.L. 1957. Evaluation of foreign fruits and nuts. No. 8. Late blossoming peach and nectarine varieties tested at Chico, California. U.S. Plant Intro Garden, California Crops Res.
Div., Agr. Res. Serv./U.S. Dept. Agr.

Arulsekar, S. and D.E. Parfitt. 1986. Isozyme analysis procedures for stone fruits, almond, grape, walnut, pistachio, and fig. HortScience 21:928-933.

Arulsekar, S., D.E. Parfitt, W. Beres, and P.E. Hansche. 1986. Genetics of malate dehydrogenase isozymes in peach. J. Hered. 77:49-51.

Durham, R.E., G.A. Moore, and W.B. Sherman. 1987. Isozyme banding patterns and their usefulness as genetic markers in peach. J. Amer. Soc. Hort. Sci. 112:1013-1018.

Goodman, M.M. and C.W. Stuber. 1983. Maize, p. 1-33. In: S.D. Tanksley and T.J. Orton (eds.). Isozymes in plant genetics and breeding. Part B. Elsevier, Amsterdam, Netherlands.

Hedrick, U.P. 1917. The peaches of New York. Rpt. New York Agr. Expt. Sta. 1916.

Messeguer, R., P. Arus, and M. Carrera. 1987.
Identification of peach cultivars with pollen isozymes. Scientia Hort. 31:107-117.

Mowrey, B.D., D.J. Werner, and D.F. Byrne. 1990. Inheritance of isocitrate dehydrogenase, malate dehydrogenase, and shikimate dehydrogenase in peach and peach $\mathrm{x}$ almond hybrids. J. Amer. Soc. Hort. Sci. 115:312-319.

Myers, S.C., W.R. Okie, and G. Lightner. 1989. The 'Elberta' peach. Fruit Var. J. 43:138-13X.

Scorza, R., S.A. Mehlenbacher, and G.W. Lightner. 1985. Inbreeding and coancestry of freestone peach cultivars of the eastern United States and implications for peach germplasm improvement. J. Amer. Soc. Hort. Sci. 110:547-552.

Stuber, C.W., J.F. Wendel, M.M. Goodman, and J.S.C. Smith. 1988. Techniques and scoring procedures for starch gel electrophoresis of enzymes from maize (Zea mays L.). North Carolina Agr. Res. Serv. Tech. Bul. 286.

HORTSCIENCE 27(1):43-44. 1992.

\title{
Use of Stored Pollen to Hybridize a Mandarin Hybrid and Citrus tachibana
}

\section{Randall P. Niedz ${ }^{1}$, Michael G. Bausher ${ }^{2}$, and C. Jack Hearn ${ }^{3}$ Horticultural Research Laboratory, U.S. Department of Agriculture- Agricultural Research Service, 2120 Camden Road, Orlando, FL 32803}

Additional index words. fruit breeding, isozymes, tachibana orange, glutamateoxaloacetate transaminase

\begin{abstract}
Fresh pollen from Citrus tachibana Macf. was oven-dried (37C), freezedried, or placed into anhydrous acetone, and stored at $-20 \mathrm{C}$ over silica gel. Pollen freeze-dried or stored in anhydrous acetone did not germinate 24 hours after treatment; oven-dried pollen germinated in 1 hour and was comparable to fresh pollen. Pollen that was oven-dried for 12 hours and stored for 1 year was used to pollinate a monoembryonic hybrid of 'Temple' (origin unknown) $\mathrm{x}$ 'Orlando' (C. paradisi Macf. 'Duncan'xC. reticulata Blanco 'Dancy'). Glutamate-oxaloacetate transaminase (GOT) isozyme profiles verified progeny hybridity.
\end{abstract}

Citrus species are all sexually compatible, although some inter- or intraspecific hybrids are difficult to create because of varying degrees of facultative apomixis (Barrett and Rhodes, 1976). Use of C. tachibana (tachibana orange) germplasm in the U.S. Dept. of Agriculture-Agricultural Research Service (USDA-ARS) breeding program has not been possible for two reasons. First, C. tachibana is highly apomictic (C.J.H. and D.J.

Received for publication 5 Mar. 1991. Mention of a trademark, warranty, proprietary product, or vendor does not constitute a guarantee by the U.S Dent. of Agriculture and does not imply its approval to the exclusion of other products or vendors that may also be suitable. We thank Delores F. Lomberk for her competent assistance and Randall C. Smith for preparing the figure. The cost of publishing this paper was defrayed in part by the payment of page charges. Under postal regulations, this paper therefore must be hereby marked advertisement solely to indicate this fact:

${ }^{1}$ Research Geneticist.

${ }^{2}$ Research Plant Physiologist.

${ }^{3}$ Research Geneticist.
Hutchison, unpublished); most seedlings are nucellar in origin, thus precluding its use as a seed parent. Second, it flowers in the Orlando area 4 to 6 weeks later than most other Citrus spp. and hybrids, thus preventing its use as a pollen parent. The purpose of this work was to determine if tachibana orange pollen could be stored for 1 year with sufficient viability to be used in controlled hybridizations.

Unopened flowers approaching anthesis were collected in Apr. 1988 from a mature C. tachibana tree growing in the germplasm collection at the USDA-ARS, A.H. Whitmore Research Farm near Leesburg, Fla. Flowers were stored in covered polystyrene dishes at $25 \mathrm{C}$ until anthesis and pollen dehiscence, and anthers were cut from the filaments with a scalpel. Fresh anthers were oven-dried at $37 \mathrm{C}$ for $3,6,12$, or $24 \mathrm{~h}$; or 4 , or $8 \mathrm{~h}$. Dried anthers were stored in 1.5 $\mathrm{ml}$ microcentrifuge tubes over silica gel at -20C. Pollen and anthers were also stored at $-20 \mathrm{C}$ in anhydrous acetone prepared by freeze-dried (-40C, 10 millitorr) for 1,2 , mixing S-mesh Drierite (W.A. Hammond Drierite, Xenia, Ohio) with acetone for $1 \mathrm{~h}$, and then filtering through Whatman no. 1 filter paper (Thomas Scientific, Swedesboro, N.J.) to remove the hydrate. The entire process was repeated two more times. This pollen was also removed $24 \mathrm{~h}$ later, washed three times in distilled water $\left(\mathrm{dH}_{2} \mathrm{O}\right)$, rehydrated, germinated, and stained.

Anthers were removed from cold storage and tested for pollen viability $24 \mathrm{~h}$ later. They were poured onto a glass slide and placed into a polystyrene dish over wet filter paper for $1 \mathrm{~h}$ to rehydrate the pollen. Pollen was germinated in Brewbaker's medium (Sahar and Spiegel-Roy, 1980) for $4 \mathrm{~h}$ at 27C, stained with Alexander's stain (Alexander, 1980), and counted to determine viability. At least 1000 pollen grains were counted per treatment. A pollen grain was considered viable if tube length exceeded grain diameter. Stored pollen was used the next season to pollinate emasculated flowers of a seedy, monoembryonic 'Temple' x 'Orlando' hybrid. Flowers were bagged after pollination, although this is generally unnecessary in Citrus breeding as honeybees, the primary Citrus pollen vectors, do not visit flowers after the petals have been removed (C.J.H. and D.J. Hutchison, unpublished), and wind is not a sig-

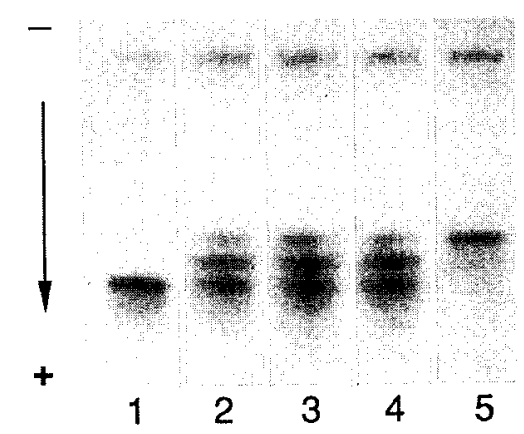

Fig. 1. GOT isozyme profiles of $C$. tachibana, 'Temple' $x$ 'Orlando' hybrids, and three hybrid seedlings. Lane $1, C$. tachibana; lanes $2-4$ hybrids of ('Temple' $x$ 'Orlando') $\times C$. tachibana; lane 5, 'Temple' $x$ 'Orlando' seed parent. 
nificant Citrus pollinating agent (Frost and Soost, 1968). Mature fruit were harvested, and seeds were extracted and germinated in a greenhouse.

Isozyme analysis was used to confirm hybridity of the seedlings produced. Leaves were collected from 4-month-old greenhouse-grown seedlings, frozen in liquid nitrogen, and powdered with a mortar and pestle. Cold (4C) extraction buffer $(50 \mathrm{~mm}$ Tris $\cdot \mathrm{HCl} \mathrm{pH} 8.4$, $150 \mathrm{~mm} \mathrm{NaCl}, 1 \mathrm{~mm} \mathrm{CaCl}_{2}, 1 \%$ insoluble polyvinylpolypyrrolidone) was mixed with the leaf powder $(0.5 \mathrm{ml}$ buffer per $0.1 \mathrm{~g}$ leaf tissue) and stirred for $15 \mathrm{~min}$. This mixture was filtered through cheesecloth, and the filtrate was centrifuged for $20 \mathrm{~min}$ at 20,000 $\mathrm{x} g$. The supernatant was collected, and the proteins were precipitated in $50 \% \mathrm{v} / \mathrm{v}$ acetone $/ \mathrm{dH}_{2} \mathrm{O}$ (assuming additive volumes) at $-20 \mathrm{C}$ for $1 \mathrm{~h}$. Precipitated proteins were freeze-dried and stored at $-20 \mathrm{C}$. Proteins were resuspended in gel buffer $\left(50 \mu \mathrm{g} . \mu \mathrm{l}^{-1}\right)$ with $10 \% \mathrm{v} / \mathrm{v}$ glycerol and $0.0002 \% \mathrm{w} / \mathrm{v}$ bromophenol blue as the tracking dye, and loaded onto the gel $(150 \mathrm{~kg} / \mathrm{lane})$. Electrophoresis was performed in a Mini-Protean II $7 \mathrm{~cm} \times 8 \mathrm{~cm} \times 0.75 \mathrm{~mm}$ slab cell (BioRad, Richmond, Calif.) using a 0.125 м Tris $\mathrm{pH} 8.8$ polyacrylamide separation gel $(8 \%$ $\mathrm{T}, 2.67 \% \mathrm{C}$ ), and cold (4C) Tris.glycine (0.025 M Tris, 0.096 м glycine, $\mathrm{pH} 8.5$ ) electrode buffer. The proteins were separated by a MacroDrive 5 automatic crossover power supply (Pharmacia LKB Biotechnology, Piscataway, N.J.) preset to $500 \mathrm{~V}, 15$ $\mathrm{mA}$, and $10 \mathrm{~W}$ before the run. Electrophoresis was stopped when the dye front reached the end of the gel or after $40 \mathrm{~min}$. Gels were stained for GOT (Torres et al., 1978) and photographed.

Anthesis and pollen dehiscence occurred 24 to $48 \mathrm{~h}$ after flower collection. Pollen freeze-dried for 2,4 , or $8 \mathrm{~h}$ failed to germinate $24 \mathrm{~h}$ after drying, but sporadic germination $(<1 \%)$ was observed in pollen freeze-dried for $1 \mathrm{~h}$. Pollen stored in anhydrous acetone for $24 \mathrm{~h}$ at $-20 \mathrm{C}$ also failed to germinate $24 \mathrm{~h}$ after treatment. Germination of oven-dried tachibana orange pollen was similar to that of fresh pollen, with $\approx 70 \%$ germination for each of the four drying times tested. Alexander's stain color contrasted well between germinated and nongerminated ovendried pollen. Pollen tubes stained red and empty pollen grains green. From these results, tachibana orange pollen was collected as described, oven-dried for $12 \mathrm{~h}$ (chosen from the four drying times for convenience), stored at $-20 \mathrm{C}$ over silica gel, and used to pollinate a hybrid of 'Temple' $\mathrm{x}$ 'Orlando' the following year. Frozen fresh pollen failed to germinate after 1 year and was not used.

Fifty flowers were pollinated in Spring 1989, and 36 fruit with an average of 11 seed per fruit were collected in Nov. 1989, Fifty seeds were germinated in the greenhouse, and seedlings were analyzed for GOT. Acceptable resolution was obtained by acetone precipitating the water-soluble proteins, freeze-drying, and running in PAGE with a low ionic strength compared with the Laemmli (1970) stacking gel buffer, and a high field strength of $9 \mathrm{~V} / \mathrm{cm}^{2}$. Resolution was decreased when the total protein concentration exceeded $3 \mu \mathrm{g} / \mathrm{lane}$.

Both parents produced a unique single band; the band from tachibana orange migrated faster than the 'Temple' $x$ 'Orlando' band (Fig. 1, lane 1). Hybrids of these clones should produce a three-band pattern, because GOT is a dimer capable of heterodimerization. All 50 seedlings analyzed had a threeband GOT profile, confirming their hybridity (Fig. 1, lanes 2-4). Confirmation of hybridity based on morphology was difficult because these two parents are quite similar, with no readily recognizable morphological markers to distinguish hybrid seedlings.

This work demonstrated that tachibana orange pollen can be oven-dried, stored at $-20 \mathrm{C}$, and used the following season in controlled hybridizations. C. tachibana exhibits significant cold hardiness for a Citrus sp. (Swingle and Reece, 1967) and may be useful in developing cold hardy citrus types. This technique accesses previously unavailable but potentially valuable germplasm, and may provide the means to overcome the problem of asynchronous flowering with other genetically valuable Citrus selections.

\section{Literature Cited}

Alexander, M.P. 1980. A versatile stain for pollen fungi, yeast and bacteria. Stain Technol. 55:1318

Barrett, H.C. and A.M. Rhodes. 1976. A numerical taxonomic studv of affinity relationships in cultivated Citrus and its close relatives. Systematic Bot. 1:105-136.

Frost, H.B. and R.K. Soost. 1968. Seed reproduction: development of gametes and embryos, p. 298. In: W. Reuther. L.D. Batchelor, and H.J. Webber (eds.). The citrus industry vol. II. Univ. of California, Berkeley.

Laemmli, U.K. 1970. Cleavage of structural proteins during the assembly of the head of bacteriophage T4. Nature (London) 227:680-68.5.

Sahar, N. and P. Spiegel-Roy. 1980. Citrus pollen storage. HortScience 15:81-82.

Swingle, W.T. and P.C. Reece. 1967. The botany of citrus and its wild relatives, p. 385 . In: W. Reuther, H.J. Webber, and L.D. Batchelor (eds.). The citrus industry vol. I. Univ. of California, Berkeley.

Torres, A.M., R.K. Soost, and U. Diedenhofen. 1978. Leaf isozymes as genetic markers in citrus. Amer. J. Bot. 65:869-881.

HoRTSCIENCE 27(1):44-47. 1992.

\title{
DNA Restriction Fragment Length Variability in the Genomes of Highbush Blueberry
}

\author{
K. Haghighi and J.F. Hancock \\ Department of Horticulture, Michigan State University, East Lansing, \\ MI 48824
}

Additional index words. RFLPs, Vaccinium darrowi, V. ashei, V. corymbosum, V. angustifolium

Abstract. Restriction fragment analyses of chloroplast DNA (cpDNA) and mitochondrial DNA (mtDNA) were carried out on the principal cytoplasms of northern highbush cultivars and one representative of Vaccinium ashei Reade. Twenty-three restriction enzymes were used to identify variation and clarify mode of organelle inheritance. All species and genotypes displayed identical cpDNA fragment patterns, but high degrees of polymorphism were observed in the mitochondrial genomes. 'Bluecrop' and 'Jersey' did not appear to have 'Rubel' cytoplasm as was previously believed. All hybrids contained maternal-type mtDNA.

Until recently, the germplasm base of the cultivated blueberry Vaccinium corymbosum L. was restricted and nuclear genes could be traced primarily to three wild selections (Hancock and Siefker, 1986). This situation has improved dramatically in the last few years as breeders have released several cultivars composed of complex species back-

Received for publication 8 Aug. 1990. Accepted for publication 28 Aug. 1991. The cost of publishing this paper was defrayed in part by the payment of page charges. Under postal regulations, this paper therefore must be hereby marked $a d$ vertisement solely to indicate this fact. grounds (Ballington, 1990; Lyrene, 1990). However, the cytoplasmic background of the leading cultivars grown in the northern production regions is still limited and pedigree records indicate that only four cytoplasms are represented in this material: 1) 'Brooks' and 'Rubel' of $V$. corymbosum, 2) 'North Sedgwick' lowbush of $V$. angustifolium Ait., and 3) 'Florida 4B' of $V$. darrowi Camp. (Hancock and Krebs, 1986). These selections represent a broad geographical and species range, but no attempts have been made to measure their degree of divergence. In this study, we used restriction fragment length polymorphisms (RFLPs) of mitochondrial and 